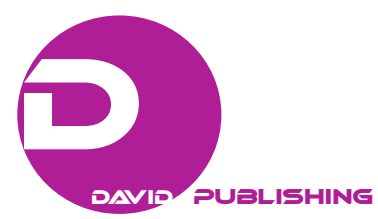

\title{
HRM and Quantitatives: Decision Tree and Vector Analysis in HRM Theory
}

\author{
Gürhan Uysal \\ Ondokuz Mayıs University, Samsun, Turkey
}

\begin{abstract}
Research topic of this paper is to discuss theory of Human Resources Management (HRM) and to discuss using of quantitative methods in HRM. Firstly, five variables establish HRM theory. They are HRM practices, positive organizational behaviors, individual performance, performance of business departments, and firm performance. Transactions among those variables enable Human Resources (HR) practitioners to apply HRM theory in their organizations. Secondly, this paper discusses use of quantitative methods in HRM. They are vector analysis and decision tree analysis. Those analyses enable HR practitioners to make effective HR decisions. Decision tree sets HR alternatives to efficiently implement HRM practices in organizations. Research question is how HR practitioners apply quantitative methods in department of HRM in firms. Finally this research comes out a conclusion that quantitative methods may be used in HRM.
\end{abstract}

Keywords: Human Resources Management (HRM) theory, vectors, matrice, decision tree, quantitative method

\section{Introduction}

This paper discusses theory of HRM and it uses decision tree analysis and vector analysis in theory of HRM.

Contribution of this paper is to explore HRM theory for HR practitioners who may apply this HRM theory in their organization. Vector analysis analyzes HRM with mathematical models and decision tree enables HR practitioners to make efficient HR decisions.

There are several HRM practices and HR practitioners may use decision tree analysis in order to make decisions related with HRM practices.

\section{Literature Review}

There are five figures in theory of HRM, which are:

(1) HRM practices;

(2) positive organizational behaviors;

(3) individual performance;

(4) performance of business departments;

(5) firm performance.

Gürhan Uysạl, Ph.D., associate professor, Ondokuz Mayıs University, Samsun, Turkey.

Correspondence concerning this article should be addressed to Gürhan Uysal at School of Business, Kurupelit Campus, Ondokuz Mayıs University, 55139 Atakum, Samsun, Turkey. Email: uysal_g@omu.edu.tr; gurhan.uysal@yahoo.com. 
HRM is developed in USA. Therefore, these figures are posed out by American HRM scholars. There are two objectives in American HRM: developing positive organizational behaviors and performance.

American HRM aims to develop positive organizational behaviors in employees' side and to increase performance of individuals and performance of firms.

According to HRM theory, firms apply HRM practices in their organizations (this is the current phase of HRM practices in global firms). HRM practices are, for example, HR planning, recruitment, career planning, compensation, performance appraisal, training, and health and safety. It is a proposition that applying HRM practices develops positive organizational behaviors in employees. Motivation, commitment, satisfaction, not intention to leave, retaining, citizenship, and trust are examples of positive organizational behaviors. It is expected that application of HRM practices in organizations develops those behaviors in employees.

According to HRM theory, positive organizational behavior leads to higher individual performance, i.e., positive organizational behavior increases individual performance of employees. This is an American concept in HR. American firms apply HRM practices to increase positive organizational behaviors of employees and this has a positive impact on individual performance.

Secondly, employees work for departments in organizational structure such as logistics departments, supply department, finance department, accounting, marketing, production departments etc.. It is expected in HRM theory that higher individual performance increases performance of those departments. If performance of employees increases, performance of supply, stock, production, marketing, finance, logistics departments may increase. So, individual performance of employees has an impact on performance of business departments.

Thirdly, performance of business departments has a positive impact on firm performance. If performance of all departments increases, firm performance increases.

This is the theory of HRM proposed in this study. The model might be shown in Figure 1.

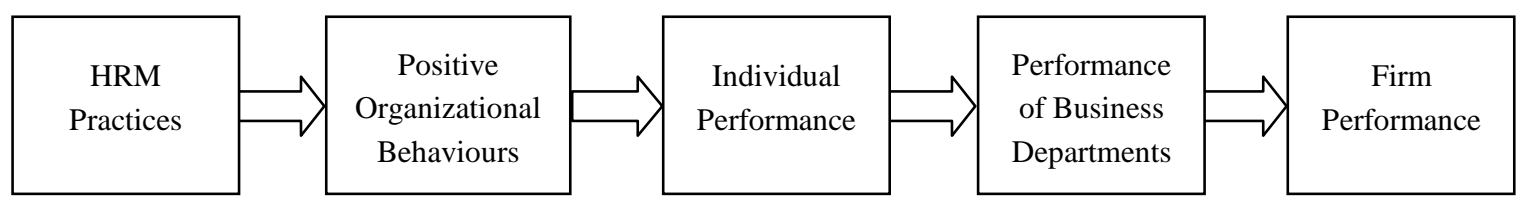

Figure 1. Dimensions of HRM theory.

Aligned with theory of HRM, firms apply HRM practices in their organizations, because it is supposed that HRM practices lead to employee's positive organizational behaviors in organizations. Consequently, positive organizational behaviors increase employee's individual performance. So, objective of HRM should be to increase performance of individuals. Employees work for a business department in organization. Therefore, higher individual increases performance of business departments. Finally, performance of business departments increases performance of firm. Therefore, individual performance has an impact on firm performance through business departments. Therefore HRM departments in organizations increase individual performance to increase firm performance.

Literature studies find that HRM practices enhance individual performance through positive organizational attitudes and behaviors (Delaney \& Huselid, 1996, p. 950). In addition, Huselid and Becker (1995) stressed that High Performance Work Practices (HPWPs) develop positive organizational behavior in employees and that has an impact on firm performance. 
How do HRM practices drive performance of firm? This is an academic question in literature. This study replies this question by HRM theory above. Accordingly, HRM practices lead to high individual performance. Higher individual performance is expected to increase performance of business departments and consequently, performance of business departments has a positive impact on firm performance. This theory of HRM may reply literature question above about how HRM drives firm performance.

Further, job performance is the key to strategic personnel management (PM). Because job performance increases department performance of business and it has an impact on firm performance. Implementing of jobs is important in PM, and efficiency of employees is important in HRM. Huselid (2012) mentioned the relationship between job performance and firm performance.

American HRM scholars recently do search for talent management in HRM. In addition, HR system and human capital perspectives are important matters in American HRM. Because both of them enhance individual performance, for example, academic researchers studied relationship between HR systems and firm performance in 1990s.

\section{Research Methods}

Research objective of this paper is to apply quantitative methods to HRM. Especially, this paper aims to apply decision tree analysis for HRM. It seems that quantitative methods can be applied by HR practitioners in firms.

\section{Analysis}

\section{Vector and Matrice Analyses of HRM Theory}

This paper aims to formulize HRM theory and set up vector and matrice equation for HRM.

Matrice is established by HRM practices in HR equation. Matrice is a mathematical model that includes interrelated or non-interrelated variables. HRM practices are made up of matrice variables in this study. Vectors are HRM department, HR professionals, and top management in equation.

Because HRM department, HR professionals and top management implement HRM practices in organizations, they are included as vector and matrice in HR equation. So, Figure 2 is shown as follow.

$$
\left[\begin{array}{c}
\text { abcd } \\
\text { efgh } \\
\text { ijk } \\
\text { lmno }
\end{array}\right]\left[\begin{array}{c}
\mathrm{A} \\
\mathrm{B} \\
\mathrm{C}
\end{array}\right]=\left[\begin{array}{l}
\mathrm{X} \\
\mathrm{Y} \\
\mathrm{Z}
\end{array}\right]
$$

Figure 2. HR equation.

In the figure above, a, b, c, d, e, f, g, h, i, j, k, l, m, n, and o are HRM practices that set up matrice in equation. $\mathrm{A}, \mathrm{B}$, and $\mathrm{C}$ are vectors. $\mathrm{A}=\mathrm{HRM}$ department; $\mathrm{B}=\mathrm{HR}$ professionals; and $\mathrm{C}=$ Top management. $\mathrm{X}$, $\mathrm{Y}$, and $\mathrm{Z}$ represent positive organizational behaviors. It is a proposition that transaction between HR matrice and vector variables leads to positive organizational behaviors in organizations. 
Secondly, first equation above is combined and it is put into HR formula below as a combination. In this HR formula:

$\mathrm{POB}=$ positive organizational behaviours

$\mathrm{IP}=$ individual performance

$\mathrm{DP}=$ department's performance

$\mathrm{FP}=$ firm performance

So, formula of HRM theory is,

$$
\mathrm{POB} \times(1 / \mathrm{DP} \times \mathrm{IP})=\mathrm{FP}
$$

This HR formula characterizes HRM theory. Aligned with, POB increases IP of employees, IP has positive impact on DP, and DP has an impact on FP. DP is represented as 1/DP in the formula because there are other factors that affect department performance in organizations than individual performance, for example, sponsorship, advertising, and pricing are factors that have a more important impact on performance of marketing department than individual performance of marketing employees.

\section{Decision Tree Analysis in Application of HRM Practices}

Decision tree is the analysis that used by operations research practitioners in firms. Decision tree establishes decision alternatives for decision makers. There are possible situations for each alternative in decision tree and practitioners set expected value for each possible situation. Then, decision makers compare value of situations and choose one option.

There are lots of HRM practices applied in organizations. This study aims to apply decision tree in HRM practices, for example, decision tree analysis will be applied in training decisions, performance appraisal decisions, and career planning decisions.

For training, it is shown in Figure 3.

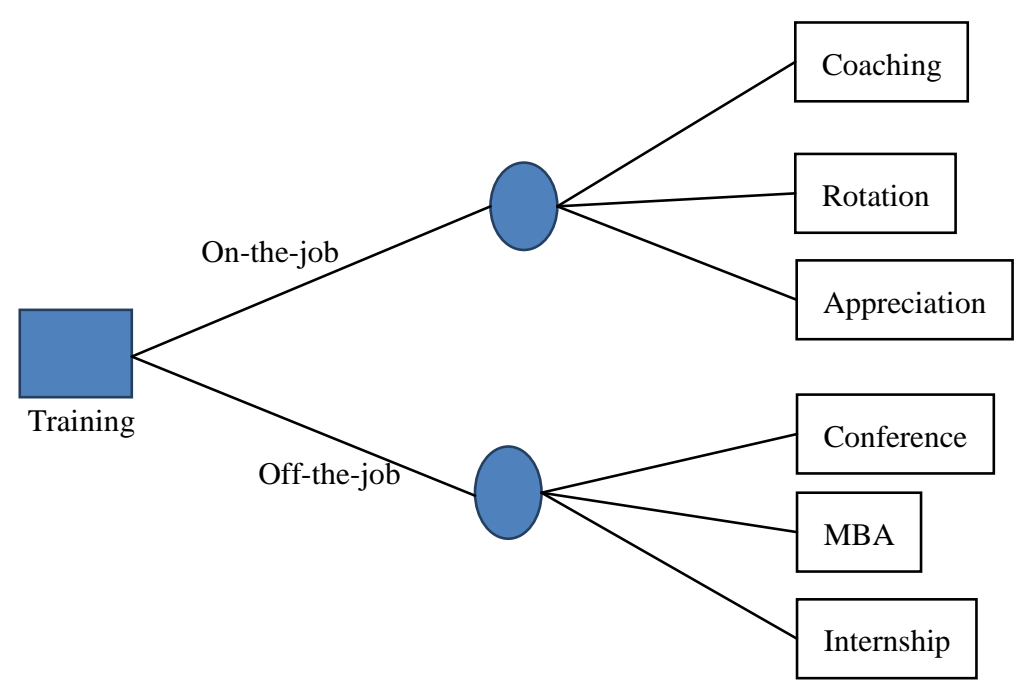

Figure 3. Decision tree analysis for training practices in firms.

In this decision tree, HR practitioners have to make decisions about their company's training practices. There are two options. Training may be applied as on-the-job or off-the-job. So, there are possible situations for these alternatives. HR practitioners compare alternatives, possibility and their values, and practitioers make decisions according to HR decision tree. 
For performance appraisal, it is shown in Figure 4.

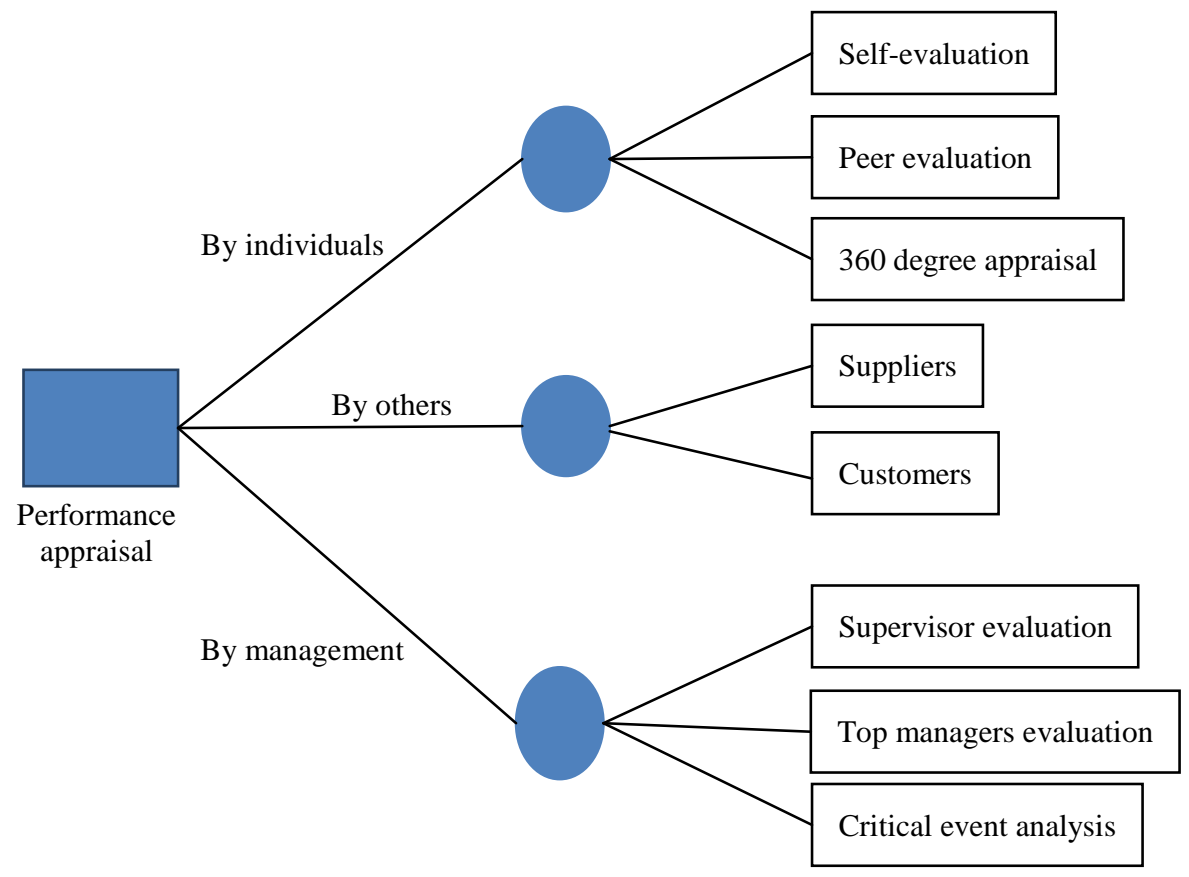

Figure 4. Decision tree analysis for performance appraisal process in firms.

There are three alternatives in this performance appraisal's tree: evaluations by individuals, evaluations by others, and evaluations by managers. Each alternative has possible situations. HR decision makers compare decision alternatives, compare expected value of each alternative, and decide to apply which policy in performance appraisal in HR.

For career planning, it is shown in Figure 5.

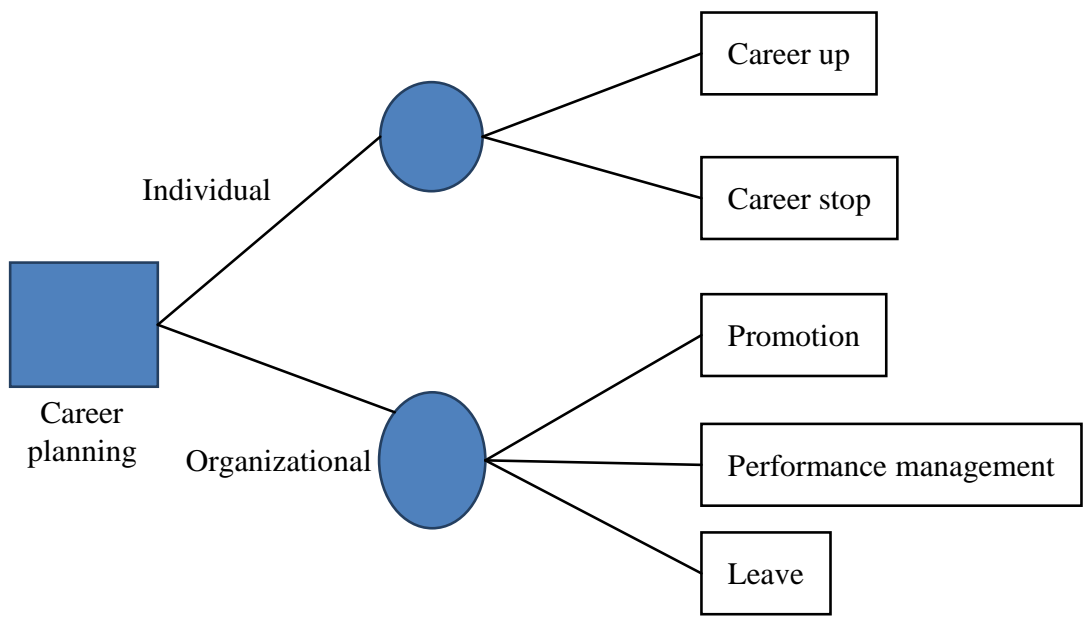

Figure 5. DT analysis for career planning in firms.

Career planning can be applied by individuals (employees themselves) and by organizations. Individual career planning has two options. Organizational career planning provides career ladder, promotion, 
performance management options in career paths. Accordingly, HR practitioners decide methods of career planning by drawing decision tree.

\section{Research Results}

Firstly, Major result of this study is that quantitative methods can be applied by practitioners in management of HR, for example, HR practitioners may use decision tree analysis to make effective HR-related decision such as training decision, career planning decision, and staffing decision.

Secondly, the other conclusion in this study is HRM theory. This study describes HRM theory for HR practitioners. Therefore, HR practitioners may practice theory of HRM in management of their firm.

Thirdly, this paper mentions importance of employee performance to achieve firm performance. In addition, this paper also argues for job performance which is important to achieve firm performance. Job performance is the topic of PM and employee performance is the topic of HRM (individual performance). Therefore, PM aims to increase firm performance through job performance, and HRM aims to increase firm performance through individual performance.

\section{Conclusions}

To conclude, this study describes theory of HRM for HR practitioners. There are five figures in theory of HRM. The most important is individual performance and firm performance.

In addition, this paper argues quantitative methods for HR practitioners. It seems that quantitative methods can be applied by practitioners in firms.

\section{References}

Delaney, J. T., \& Huselid, M. A. (1996). The impact of human resource management practices on perceptions of organizational performance. Academy of Management Journal, 39(4), 949-969.

Huselid, M. A., \& Becker, B. E. (1995). The strategic impact of high performance work systems (in progress).

Huselid, M. A. (2012). A focus on the design, implementation, and measurement of the HR and workforce strategies. Proceedings from Krannert HR Executive Conference, New Jersey. 